УДК 140.8:316.356.4: 272] (477) Конрад

DOI 10.35423/2078-8142.2019.1-2.04

О. Ю. Шеремета, кандидат філософських наук, молодиий науковий співробітник Інституту філософї імені Г. С. Сковороди НАН Украӥни e-mail: osheremeta2015@gmail.com ORCID: https://orcid.org/0000-0001-8364-4300

\title{
о. МИКОЛА КОНРАД: ФОРМУВАННЯ УКРАЇНСЬКОЇ НАЦІОНАЛЬНОӤ ІДЕНТИЧНОСТІ У КОНТЕКСТІ ПРОБЛЕМИ «НАЦІОНАЛІЗМ ТА КАТОЛИЦИЗМ»
}

У статті висвітлюються погляди о. М. Конрада на націоналізм та пов'язані з ним поняття: національна ідентичність, нація, національна держава у контексті проблеми «націоналізм та католицизм», які він висловив у доповіді під назвою «Націоналізм та католицизм», написаній для виступу на Академічних вечорах Богословського Наукового Товариства.

Проведене дослідження дало можливість, на основі аналізу основоположних понять націоналізму, з'ясувати бачення М. Конрадом альтернативного вчення до інтегрального націоналізму Д. Донцова - націоналізму католицького. Також ствердити, щчо мислителю вдалося розвинути власне трунтовне $і$ виважене бачення проблеми, яке можна окреслити як католищький наџіоналізм. У результаті вивчення його ідей було з 'ясовано, що вони містяться на межі двох філософських напрямів - неотомізму та політичної філософії. Однією з причин ідеї розвитку націоналізму на християнських засадах була потреба протиставити їі інтегральному націоналізму Д. Донцова, який перебував під впливом філософії Ф. Ніџше. Спільність розуміння поняття національної ідентичності, сутності націоналізму та його видів Конрадом і сучасними мислителями (В. Лісовий, О. Проценко, Е. Сміт) свідчить про дале-

(C) Шеремета О. Ю., 2019 
коглядність та актуальність ідей отия у изарині політичної філоcopii.

Порівняння доповіді М. Конрада з прачями польських мислителів Я. Воронецького та Ю. Бохенського дало можливість ствердити, щуо його ідея католищького націоналізму розвивалася у межах політико-філософського дискурсу з розвитку, поширення та впровадження начіоналістичних ідей як у польському, так $і$ в украйнському середовищі. М. Конрад, Я. Воронецький та Ю. Бохенський намагалися розглядати проблему націоналізму на засадах раннього неотомізму, зокрема вчення про природній закон, загальне добро, вчення про державу, застосовуючи його до проблем тогочасного суспільства.

Ключові слова: неотомізм, політична філософія, начіональна ідентичність, начіоналізм, нація, начіональна держава

Національна ідентичність є одним із головних понять націоналізму та тісно пов'язане з нацією. Е. Сміт відзначав, що сформувалася вона порівняно недавно, замінивши поняття «національна свідомість» та «національний характер», які функціонували y XVIII, XIX та на початку XX ст. [1, с. 16, 31]. Дослідник виокремлює три найважливіші цілі, які визначають добро нації - національна автономія, національна єдність та національна ідентичність [1, с. 21]. Відтак національна ідентичність є не лише фактом, що свідчить про існування нації, а й певним прагненням (метою) нації, необхідною визначальною властивістю, яка демонструє іiі самобутність та неповторність. Е. Сміт дає таке іiі визначення: «безперервне відтворення й нове тлумачення властивих вартостей, символів, пам'яті, мітів і традицій, які утворюють особисту спадщину нації, а також ототожнення індивідів 3 цими ознаками, спадщиною й складниками культури» [2]. Це поняття не втрачає свого значення і сьогодні та продовжує відігравати важливу роль у становленні та розвитку націй.

Питання націоналізму та пов'язаних з ним понять у контексті вчення Католицької Церкви досліджував український мис- 
литель отець Микола Конрад. Він жив та працював у міжвоєнний період, коли українська нація на короткий час здобула незалежність та, на жаль, втратила їі. Дослідженню його біографії присвятили свої праці В. Савран, Б. Головин, о. М. Шаварин та ін. Однак наукова спадщина мислителя ще потребує вивчення.

Свої думки щодо націоналізму М. Конрад висловив у доповіді під назвою «Націоналізм та католицизм», складеній для виступу на Академічних вечорах Богословського Наукового Товариства (Далі БНТ. - О.Ш.), заснованого 1923 р. 3 ініціативи о. д-ра Тита Галущинського, ректора Львівської ГрекоКатолицької Духовної Семінарії [3, с. 14-17]. Їі текст вийшов друком у кількох випусках часопису «Мета» за 1934 р. Того самого року він був виданий брошурою Українським Католицьким Союзом.

Відзначимо, що серед різновидів діяльності БНТ на особливу увагу заслуговують Академічні вечори. Не зважаючи на науково-популярний характер заходів, доповідачі намагалися у доступній формі викласти певний науковий матеріал, зокрема 3 філософії, та свою думку щодо нього. У їх межах філософія виходила поза стіни академічних аудиторій та богословськофілософського середовища. Набираючи науково-популярного стилю вона ставала доступнішою та зрозумілішою для широкого кола слухачів.

Академічні вечори користувалися популярністю серед галицької інтелігенції. У 1934 та 1935 роках вони відбувалися у різних населених пунктах Східної Галичини (понад 60) [4, с. 114]. Загалом 31933 до 1938 рр. у різних населених пунктах було виголошено близько 124 доповіді. Їх могло бути і більше, якби не складні політичні процеси, які мали місце на західноукраїнських теренах та у світі. Останній Академічний Вечір відбувся у Львові за кілька днів до німецького бомбардування [3, с. 29-30]. У циклі Академічних Вечорів було проголошено кілька доповідей 
о. Миколи Конрада, однак у цьому дослідженні особливу увагу приділимо доповіді, присвяченій націоналізму.

За спостереженням о. Миколи Конрада, націоналізм набув популярності у багатьох країнах Європи, зокрема в Польщі. Однак значно впливала на суспільні процеси і Католицька Церква. Така ситуація створювала умови для політико-філософського дискурсу на тему «Католицизм і націоналізм». Водночас, авторитет Католицької Церкви сприяв поширенню філософії неотомізму. Із неотомістичних позицій про націоналізм та католицизм писали польські мислителі о. Яцик Воронецький та о. Юзеф Марія Бохенський (який значно розвинув погляди Воронецького). У цьому контексті вибір о. М. Конрадом тематики дослідження про католицизм та націоналізм був актуальним та відповідав запитам українського суспільства. Йому вдалося сформувати власні політико-філософські ідеї на засадах вчення Томи Аквінського.

Як відзначає Василь Лісовий, основні питання, які прагнуть розв'язати дослідники націоналізму, такі: що таке націоналізм, його типологія, джерела становлення і поширення ідеології та ії перспективи; нація як основний концепт та цінність ідеології націоналізму [5, с. 81]. Подібним чином свою доповідь будував i о. Конрад.

\section{Націоналізм}

У вступі, окреслюючи проблему, М. Конрад твердить про протилежні точи зору у ставленні до націоналізму: від негативної, представленої поглядами Рабіндраната Тагора, до позитивної, яка, на основі фактів популярності націоналізму у більшості тогочасних країн Свропи, Азії та Африки, навіть у більшовиків, а також його впливу на Католицьку церкву, доводить наявність притаманних йому цінностей. Однак, чим саме буде націоналізм - чи «сонцем нового світу», чи нищівною «жахливою пожежею», залежатиме від того, з яких джерел він черпатиме свою основу [6, с. 3-4]. У такий спосіб автор вказує на властивість терміна «націоналізм» набувати протилежних значень. У цьому 3 52

Institute of Philosophy of H. S. Skovoroda of NAS of Ukraine 
ним погоджуються і сучасні дослідники. Так, В. Лісовий та О. Проценко, цитуючи П. Альтера, акцентують увагу на тому, що націоналізм може означати як звільнення, так і гноблення; може містити в собі як позитивні можливості, так і загрози; може набувати різних форм та різновидів, схиляючи говорити радше про різноманітні його прояви, ніж про існування єдиного явища $[7, \mathrm{XII}]$.

Відтак Конрад переходить до відповіді на питання: що таке націоналізм? Визначення націоналізму у нього тісно пов'язане 3 патріотизмом, на що вказує вже сама назва пункту «Націоналізм - патріотизм». Неоднозначність розуміння терміна - це перше, на що звертає увагу о. Конрад. Щоб уникнути непорозумінь, він обговорює націоналізм у цьому пункті у «давнішньому значенні того слова, що його називають сьогодні «патріотизмом», «культурницьким націоналізмом», «народництвом», а тоді продовжує, що «націоналізм в давнішньому розумінні означає думку, погляд, що вважає добрим і слушним поділ людства на нації та їм признає повне право до найдосконалішого розвитку» [6, с. 5].

Націоналізм у певному розумінні стає логічним розвитком патріотизму у поглядах Конрада. Із появою націй патріотизм дістає нового забарвлення, а саме - національного. Відбувається зміна акценту. Народ стає нацією, виростає до усвідомлення своєї окремості від інших та прагне повноцінного розвитку не лише на власній території - Батьківщині, а й у власній державі, на своїй землі. Тому важлива не лише любов до Батьківщини, а й до нації. Конрад підкреслює, що цей процес є добрим і слушним, та надає націям право найдосконалішого розвитку. Попри зміну акценту Конраду важливо вказати і на історичний розвиток націоналізму та його зв'язок з патріотизмом. На труднощі, що виникають із розмежуванням понять «націоналізм» та «патріотизм» у національних рухах, вказує і В. Лісовий [8, с. 338]. Його дослідження наштовхнуло на думку про те, що патріотизм практично став одним 
зі складників націоналізму у баченні Конрада, а тому чітко розрізнити ці поняття неможливо.

3 таким розумінням націоналізму погоджується католицька етики. Такого націоналізму, на думку мислителя, домагаються закони природи і добро людства. Однак Конрад вбачає своє завдання в тому, щоб показати, чому саме важлива ця згода. Із цією метою він протиставляє його інтернаціоналізму, який тлумачить як «думку, що осуджує поділ людства на нації і прямує до того, щоби усувати національні різниці між людьми і виробити такі типи космополітів, що почували би себе безпосередньо приналежними до цілого людства», а далі додає, що такими в давнину були стоїки, «а тепер прямують до цього соціалісти й комуністи» [6, с. 5]. Конраду важливо знайти спільне бачення націоналізму та католицизму, щоб не допустити крайніх проявів розвитку цієї ідеології та знайти в ньому союзника у боротьбі проти соціалізму та комунізму - ідеологій, які також загрожують розвитку суспільства.

Трохи інший підхід до націоналізму представлений у праці «Націоналізм та католицизм» о. Яцика Воронецького [22]. Польський неотоміст вважав, що настав слушний момент для того, щоб католицькі моралісти приступили до питання націоналізму 3 метою дослідити, яку роль Проведіння Боже призначило національному чиннику в моральному розвитку людини [10, с. 62]. У своєму досліджені «Націоналізм та католицизм» Воронецький зупинився на деяких істотних проблемах націоналізму, які потрібно розглянути у світлі християнської моралі. Вони є потрійними: перша - яке значення для повноти морального розвитку людини має життя, вміщене у національні межі, та що у ньому відіграє більшу роль - держава чи нація; друга - чи моральні права, які керують діяльністю держави та нації, є такими самими, як ті, що зобов’язують людину; третя стосується співвідношення між життям національним та життям надприроднім [10, с. 63, 67-68].

У такий спосіб Воронецький відмежовується від визначення націоналізму як такого, ставить його на другий план й одразу пе54

Institute of Philosophy of H. S. Skovoroda of NAS of Ukraine 
реходить у площину моралі. Не розкриває і проблеми християнського патріотизму, лише згадує про нього у контексті проблеми співвідношення національного та надприродного життя людини, набуття нею надприродних чеснот (осягнути їх не можна без Божої Ласки, благодаті), найбільшою з яких є любов. Християнський патріотизм Воронецький розглядав як один з ії проявів, який, зокрема, реалізується у покликанні солдата - захисника.

Воронецький, за св. Томою, відзначає, що Ласка Божа не нищить природи, але іiї очищає, підносить та вдосконалює. Так само і життя національне очистить, удосконалить та продуктивність його діяльності збільшить [10, с. 68-69]. Питання Ласки Божої та відношення до неї людської природи тісно пов'язане з баченням проблеми відносин між державою та Церквою в Аквіната [11, с. 170]. Діяльність, відповідно до чесноти, за Томою Аквінським, є однією з підстав доброго життя людини [12, с. 257]. Однак людина є істотою суспільною, а тому потребує життя у спільнотах, найдосконалішою з яких $є$ держава. Тому в Аквіната держава $\epsilon$ спільнотою досконалою. Однак досягнення спільного добра не $\epsilon$ можливе без державної влади, яка повинна про нього дбати так само, як і про забезпечення доброго життя для одиниці. Без неї кожен дбав би лише про власне [11, с. 172]. Про державну владу як елемент об'єднувального чинника для спільнот людей, якими $€$ держави та нації, твердить і Я. Воронецький [10, с. 17].

Як така, що $є$ певною мірою автономною, людина може осягнути дочасну мету існування - дочасне щастя, яке реалізувати можливо у спільноті політичній, тобто державі. Однак кінцеву мету свого існування людина (життя вічне) не може осягнути без Ласки Божої. Тому у св. Томи держава підпорядкована Церкві, щоб бути удосконаленою через неї так само, як природа людини через Божу Ласку [11, с. 187].

Бохенський доповнює думку Воронецького про любов до ближнього. Він пише, що католицизм, попри його універсалізм, суперечний механічному інтернаціоналізму, згідно з яким немає 
відмінностей між людьми і всі повинні любити один одного однаковою любов'ю. За св. Томою, Бохенський визначає ступені любові. Так, тих, хто до нас найближчий, ми повинні більше любити, ніж тих, хто далі. Згідно з католицизмом, любов не повинна руйнувати ні природу людини, ні культуру. Кровна спорідненість та культурні зв'язки об'єднують людей, а тому любов до тих, хто з нами однієї крові чи однієї культури, має бути сильнішою, ніж до інших. Звідси, за Бохенським, перед любов'ю до всього людства є любов до сім’ї, а особливо - до нації [13, с. 28].

Відчуття патріотизму Воронецький пов'язував із християнською чеснотою любові до ближнього та порядком послідовності її вияву, а не з визначенням поняття націоналізму, як у Конрада. Його він не формулює. Бохенський, натомість, намагається дати визначення націоналізму. Розпочинає з твердження, що націоналізмом називає доктрину, яка передбачає, що представники нації повинні прагнути втілення специфічних завдань нації, зокрема зберігати та розвивати притаманні їй цінності. Націоналізм як настанова $є$ відчуттям специфічно національних цінностей та комплексом відчуттів, що схиляють до діяльності відповідно до них. Загалом, питання існування націоналізму, зрозумілого у такий спосіб, зводиться, якщо йдеться про саме його існування, до питання буття нації $[13$, с. 86]. Акцент на націоналізмі як на доктрині, яка спонукає націю не лише до збереження цінностей, а й до реалізації певних іiі завдань, перегукується з баченням певного месіанізму й суттєво відрізняється від бачення націоналізму як ідеї, що не лише легітимізує поділ людства на нації, а й надає право на найдосконаліший їх розвиток.

\section{Нація}

У Сміта формування визначення нації розпочинається з розгляду двох моделей нації та виокремлення елементів національної ідентичності. Першою він розглядає західну модель. Її компонентами Сміт вважає історичну територію, політикоюридичну спільноту, політико-юридичну рівність членів, спіль56

Institute of Philosophy of H. S. Skovoroda of NAS of Ukraine 
ну громадянську культуру та ідеологію. Визначальною рисою незахідної, «етнічної моделі», притаманної Східній Свропі та Азії, є, на думку дослідника, наголос на спільності походження та рідної культури. На відміну від західної концепції, згідно 3 якою індивід може сам обирати, до якої нації йому приєднуватися, у незахідній моделі людина завжди залишатиметься членом спільноти, в якій вона народилася [14, с. 20]. Е. Сміт відзначає, що те місце, яке має закон у західній громадянській моделі, в етнічній посідає народна культура, здебільшого мова та звичаї. Тому, на його думку, лексикографи, філологи та фольклористи відігравали центральну роль на різних етапах розвитку націоналізмів у Східній Свропі та Азії. Їхні лінгвістичні та етнографічні дослідження давньої і сучасної культури «простого народу» забезпечили матеріал для проектів створення «майбутньої нації» [14, с. 21].

У підсумку, Сміт стверджує, що елементами етнічної концепції нації є генеалогії і нібито спільне походження, мобілізація народу, рідна мова, звичаї і традиції. Вона відображає зовсім інший шлях «формування націй», пройдений багатьма спільнотами у Східній Європі та Азії, та становить сильний політичний виклик, який відбиває глибокий дуалізм, що лежить в основі всякого націоналізму. Адже кожен націоналізм містить громадянські та етнічні елементи в різних пропорція і формах. Часом, на думку Сміта, переважають громадянсько-тереторіальні елементи, а часом - етнічні та народно-культурні [14, с. 21-22].

За Смітом, конкретні моделі нації передбачають певні спільні погляди на те, що, власне, становить націю, відрізняючи від усіх інших різновидів колективної ідентичності. Наявність тих спільних тверджень дала Сміту можливість сформувати риси національної ідентичності та визначення нації. Отже, головні риси національної ідентичності: історична територія, або рідний край; спільні міфи та історична пам'ять; спільна масова громадянська культура; єдині права та обов'язки для всіх членів; спі- 
льна економіка з можливість пересуватись у межах національної території. Відповідно націю визначає як сукупність людей, що має власну назву, свою історичну територію, спільні міфи та історичну пам'ять, спільну масову громадянську культуру, спільну економіку і єдині юридичні права та обов'язки для всіх членів [14, с. 23].

Визначення нації як такого Конрад не подає. Однак розглядає це поняття у контексті вчення про спільне добро. Він стверджує, що націоналізм у згаданому розумінні вимагає добра цілого людства. Людство порівнює з організмом, добро якого залежить від кожного органу, який працює не лише для власного добра, а й для добра цілого організму. Кожна нація є органом людства і приносить його збірній культурі особливу данину. Природа, життєвий процес визначає націям особливе завдання та наділяє їх відповідними прикметами й силами. Конрад відзначає: «Як індивідуальність одиниці не є лихом для громадянства, а навпаки, їі розвиток та завершення причиняється для загального добра, - так індивідуальність нації не є лихом для людства: вона $\epsilon$ великим різноманітним і всестороннім добром загалу» [6, с. 67].

Нація - угруповання природне, а інтернаціональні угруповання можуть бути корисні для виконання деяких спеціальних завдань. Однак вони не можуть охоплювати цілості життя та створювати для нього межі, а коли намагаються це зробити, хоча б в окремих важливих його ділянках, стають протиправними $\mathrm{i}$ шкідливими [6, с. 7]. Таким чином, отець обстоює думку важливості існування нації з позицій томістичного вчення про спільне добро, вбачаючи в ній цінність для культури людства. Саме поняття нації пов'язане у нього з національною ідентичністю, про яку він пише у контексті вчення про природній закон.

Закон природи сприяє утворенню націй, вважав Конрад. За Арістотелем, людина є суспільним єством. I закон природи домагається суспільного життя людства, а його наслідками є: спільне походження, кровна спорідненість, расова спільність, спі- 
льна мова, спільна територія, звичаї, традиції, переживання, а на завершення - культура, релігія, державність. Усе це разом впливає на спільну подібність фізичних і психічних властивостей людей певної групи, на їх почуття спільноти і відмінності від інших груп. Так, на думку Конрада, постає нація [6, с. 5]. Він відзначає, що нація бере початок у глибокій давнині, від одного роду, одного племені, у такий спосіб вказуючи на спільне походження іiі представників. Перелік рис національної ідентичності мислитель доповнює наявністю спільної історії.

Про згадані фактори цікавою є думка Е. Сміта. Він зауважує, що нація - це основоположне поняття націоналізму, однак воно є найсуперечнішим та найпроблематичнішим у ньому. Його означення залежить від того, на які чинники дослідники звертають увагу - суб'єктивні (мова, релігія, звичаї, територія, інституції) чи об’єктивні (ставлення, сприймання та почування). Або ж від намагання об'єднати «об'єктивно-суб'єктивний» спектр. А також від з'ясування, чим нація не є - це не державне утворення та не етнічна спільнота, хоча межа між нацією та етнічною спільнотою не чітко окреслена. Їх суттєві відмінності полягають у наступному: нації відрізняються атрибутами спільних прав i обов'язків для всіх представників та єдиною економікою; нації, зазвичай, завойовують батьківщину, тоді як етнічні спільноти можуть бути тільки пов'язані (символічно) зі своїм рідним краєм; етносам не конче мати національну культуру, а тільки деякий спільний культурний складник, як от мову, релігію, звичаї або спільні інституції, натомість спільна національна культура основний атрибут націй: в етносів трапляються розмаїті традиції пам'яті, а у націй - систематизована, стандартизована національна історія [2].

Саме поняття «національна ідентичність» Конрад не використовує, натомість вживає «національне самовідчування та самосвідомість», що є властивим науковій термінології досліджуваного періоду, що відзначав Е. Сміт. Також дослідник твердить 
про суб'єктивний та об’єктивний чинники у творенні нації, перелічує риси національної ідентичності та їх усвідомлення й сприйняття представниками нації.

На думку Конрада, природне оточення, народна, пісенна, музична, мовна культура витворюють національний дух, який «проявляється у національно-етнографічних своєрідностях і культурних надбаннях, а саме в мові, піснях, одягах, звичаях, своєрідних формах суспільного, культурного, економічного і політичного співжиття громадян» [6, с. 6]. За визначенням Е. Сміта, М. Конрад пише про етнічну модель нації, не етносу, з власною ідентичністю. Походження нації вбачає у культурі в широкому значенні слова, яка охоплює всі сфери життя людини. Релігію виокремлює. Однак своє бачення нації доповнює політичною культурою співжиття громадян у власній державі, а це, за розрізненням Лісового та Проценка $[7, \mathrm{xxv}]$, дає можливість розмістити його модель нації між етнічною та політичною.

Поняття «національна ідентичність» не застосовуе i Я. Воронецький. Розмірковуючи про національні особливості, він обмежується поняттям «єдності» та ㄲï складових, яка об'єднує людей у спільноти - як національні, так і державні. Відмінність складників дає людям змогу, на думку одних, належати до одної спільноти, а на думку інших - до другої. Так, єдність, встановлена завдяки державній владі, творить громадянську суспільність, яка називається держава. А єдність, яку творять моральність та звичаї, а також кровна спорідненість (оскільки часто нація є продовженням одного роду чи племені), єдність мови та релігії є підставою для виникнення нації [10, с. 1617].

У Воронецького походження нації пов'язане зі звичаями народу, які визначають моральність вчинків його одиниць. Це питання він розглядає у межах першої проблеми свого дослідження. Воронецький задається питанням: звідки походить потреба жити в межах нації? Потреба певної конкретної допомоги, яку одиниці дає національний організм, стосується дуже 60

Institute of Philosophy of H. S. Skovoroda of NAS of Ukraine 
суб'єктивного чинника вродженої потенційності людини, браку рішень у неї щодо способу виконання тієї чи іншої дії. Людина за своєю природою не має досконало окреслених схильностей, котрі щохвилини керували б ії моральною діяльністю. Вона виробляє їх у результаті виховання. У національному середовищі людина народжується та починає формуватися морально [10, с. 64-65]. Нація постає у Воронєцкого як певний звичаєвий зв'язок між ії членами, який має підготувати людину до вибору морального добра [10, с. 5-10]. Тому вона постає першорядним, головним виховним чинником. Звичаї у польського етика $є$ одні-

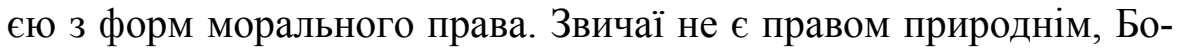
жим чи навіть людським, однак люди часто-густо підпорядковуються їм. Вони не є незмінними, навпаки, повинні змінюватися, особливо коли суперечать праву природному чи Божому. Однак саме звичаї, навіть якщо лише у справах другорядних, котрі, проте, сповнюють життя людини, $є$ найважливішим елементом національної єдності [15, с. 303-305].

Нація, на думку Бохенського, не є відмінною від інших суспільних груп. Ті риси, які зазвичай приписуються нації, приписуються і давнішим меншим суспільствам (наприклад, грецький поліс). Він припускає, що можливо за певний час будемо їх приписувати суспільствам, більшим від нації [13, с. 65]. Бохенський доходить висновку, що поняття нації не можливо сформулювати, оскільки воно збірне. Він виокремлює риси, які зазвичай вважають притаманними нації, серед яких: спільна мова, спільна історія, звичаї, держава і т.п. Так, різні нації мають спільну історію, але трапляється й так, що у представників однієї нації є різна історія. Те саме стосується і мови: існують різні нації з однією мовою, але $\epsilon$ й єдині нації, які використовують різні мови [13, с. 68].

Подібно Бохенський відзначає і певні вроджені психічні особливості (риси), або як кажуть «порода психічна» (вдача психічна, або психічний характер). Однак, сучасна наука нічого не може сказати про психічні властивості конкретних націй. Наступ- 
не, за томістичною теорією залежності психіки від тіла, що вроджені психічні особливості залежатимуть від типів антропологічних. У Польщі, на думку Боденського, не можна знайти спільного вродженого психічного типу. Можна говорити про специфічне національне почуття. Та не можна знайти щось конкретно відмінне у національних почуттях певної нації та інших націй. Та й почуття не підлягає зовнішньому спостереженню, а тому використання його як підгрунтя теорії призводить до розгубленості та браку предметності [13, с. 69].

Однак інша справа, на думку Бохенського, коли йдеться про властивості, набуті завдяки вихованню та впливу історичного середовища. Відомо, що кожні суспільні групи, які мають спільну історію, звикли створювати власний звичай, власний спосіб виховання, власний відтінок етики, а точніше - власну культуру $[13$, с. 70]. Тут Бохенський наслідує Воронецького, який вважав, що спільні звичаї є найособливішою з підстав єдності нації (кровна спорідненість, мова, релігія) [10, с. 17]. Однак Бохенський виводить поняття «нації» 3 культури.

Ю. М. Бохеньський розуміє націю як зібрання людей, об’єднаних спільним позитивним ставленням до певної групи культурних цінностей. На думку Бохенського, складно визначити, яка конкретно група культурних цінностей потрібна для утворення нації. Адже завжди можуть знайтися винятки, які заперечать універсальність тієї чи іншої цінності. Тому Бохенський звертається до суб'єктивного чинника - інтуїції осіб, які визнають свою належність до певної національності. Мислитель переконаний, що риси, які формують належність до нації, слід шукати не в самих цінностях (територія, мова, раса), а в особистому ставленні до окремих цінностей [13, с. 46].

Походження нації та національну ідентичність Бохенський розглядає в контексті проблеми національного католицизму, забарвленого національними особливостями. Чи такий можливий? Дослідник вважає, що так. У цьому контексті він пише про психіку нації та ¥ї національний характер. Бохенський стверджує, 62

Institute of Philosophy of H. S. Skovoroda of NAS of Ukraine 
що кожна нація має свої чуттєві реакції, вольові та емоційні настанови пов’язані з їі психікою. А тому може існувати і певний відтінок, а саме про нього йшлося, національного католицизму, французького чи польського, наприклад. Далі переходить до опису характеру. Усі католики не повинні мати однаковий характер. Так само і нації. Не є неможливим, щоб нації, виховуючи національний характер, виховували одночасно своєрідне розуміння комплексу питань католицького світогляду. У багатьох проявах релігійного життя існують помітні відмінності між націями. Тобто, релігійна сфера життя нації теж формує їі відмінність від інших націй. Повертаючись до поняття «нація» Бохенський уточнює, що під ним розуміє суспільну групу, котра єднає людей передусім за подібністю культурних особливостей, отже - виводить походження цього поняття з культури [13, с. 49-52].

Із кінця XIX ст. до закінчення Другої світової війни термін «національний характер», який вжився на означення національної ідентичності, був тісно пов'язаний з психологією народів, котра виросла із психології мас. До недавна вважалося, що проблема психологічної відмінності не охоплює площину націоналістичної спекуляції (Ю. Яронь). Однак вихідним пунктом націоналістичних концепцій були і залишаються роздуми про поняття нації, прагнення до окреслення національного характеру (Л. Здибель) [23]. Це пояснює вживання М. Конрадом та Ю. Бохенським термінів на означення національної ідентичності, пов'язаних із психіко-ментальними ознаками. Польський національний характер у міжвоєнний період тісно пов'язаний 3 католицьким віровизнанням, тому не дивно, що Бохенський пише про нього у контексті національного католицизму.

\section{Держава}

Націоналізм - це не лише мовна і культурна ідея певної нації, вважав Конрад, а й національно-політична та державницька. Найбільшою кривдою для поневолених націй є їх денаціона- 
лізація. Найкращі умови для повноцінного розвитку нації створює національна держава, яка сприяє збереженню незалежності, осягненню загального добра, запобігає небезпекам. Державний правовий націоналізм суперечний імперіалізму, бо дає право розширювати свої кордони лише до національно-етнографічних меж. Такий націоналізм є прийнятним для католицизму, на відміну від пересадного національного егоїзму [17, с. 2].

У такий спосіб Конрад окреслює певні види націоналізму. Ïx можна типологізувати більш чітко за допомогою термінів, пропонованих В. С. Лісовим. Конрад твердить про етнічний націоналізм, яким позначають політичний рух етнічних груп та національних меншин за розширення своїх прав (політичної автономії чи незалежності). Цей термін застосовують і до державного націоналізму, якщо його основою $є$ певна національна більшість (корінний етнос, титульна нація). Конрад, за типологією Лісового, розглядає й експансіоністський націоналізм (переважно державних націй) та захисний (переважно не державних націй) $[5$, с. $104-110 ; 18$, с. 412].

Далі Конрад веде мову про розуміння націоналізму як національного егоїзму. Як приклад наводить ситуацію в гітлерівській Німеччині, де національний соціалізм спирається на містиці раси та фізичній мілітарній силі, а державу вважає за засіб удосконалення німецької раси. Лісовий зазначає, що розуміння націоналізму як національного егоїзму не враховує того, що націоналізм може виступати і як рух за звільнення. Цю тезу підтримує і Конрад.

Дослідник акцентує увагу на поширенні націоналізму у багатьох країнах Європи, зокрема Англії, Польщі, Литві. Далі переходить до формування українського націоналізму, який повстав у боротьбі за волю України та «прямує до здобуття революційними засобами Самостійної, Соборної Української Держави. Він $є$ визвольним рухом поневоленого народу» [19, с. 3]. Конрад відзначає, що цей рух сягає 1920-го року, відмежовуючи його у такий спосіб від фашизму та гітлеризму. Був популярний серед 
молоді та активно боровся 3 комуністичними організаціями, що набули популярності у іï середовищі. Однак, після перемоги над ними, попав під вплив Д.Донцова, якого далі критикує насамперед за волюнтаризм. В.Лісовий дотримувався думки, що український інтегральний націоналізм виникає у результаті поразки визвольних змагань як захисна реакція на утвердження авторитарних і диктаторських режимів у сусідніх державах та поширення ідей інтегрального націоналізму у Західній Європі. Філософськими засадами політичної публіцистики Донцова визнавав елітаризм, волюнтаризм, ірраціоналізм [20, с. 253-261].

У Воронецького поняття «держава» тісно пов'язане 3 поняттям «нація» та «людська одиниця». Його він розв’язує у межах першої проблеми: що відіграє більшу роль у моральному розвитку людини - держава чи нація? Чимало католицьких моралістів у Німеччині, на думку Воронецького, підтримують ідею першості держави, а не національностей [10, с. 63]. Однак Воронецький схиляється до протилежного висновку, а саме - про першість у моральному житті людини саме нації, оскільки саме національний чинник $є$ у вродженому порядку головним виховним чинником.

Усі люди підпорядковуються прагненню осягнути кінцеву мету існування - вічне життя. Звідси, за Воронецьким, походить потреба жити в державі. Якщо в особистому житті для досягнення мети кожен сам дбає про засоби, то у суспільстві бажано, щоб була збережена організаційна єдність. Таке рішення має походити від центрального органу, від певного авторитету, який формує підставу суспільної єдності для членів суспільства. Цією природною підставою громадянської єдності держави є громадянські права, які їі вінчають [10, с. 64].

Зрозуміло, що людина зобов'язана жити у межах як нації, так і держави. Тому найкраще, щоб між цими суспільними організмами панувала гармонія. На думку Воронецького, з позицій християнської етики варто подивитися на національно однорідну 
державу як на ідеал, реалізація якого є дуже позитивна для морального розвитку громадян. Однак слід пам'ятати, що його реалізація не завжди можлива. Та й досягати його шляхом підривання основ існуючого ладу не є слушним, особливо якщо це може зашкодити моральному життю громадян [10, с. 65-66]. Хоча у моральному розвитку людини Воронецький надавав перше місце нації, проте права держави над ії громадянами, навіть різних національностей, не обмежував. Провідну роль для морального життя людей відігравала Церква, тому і в державі їй мала належати провідна роль.

Воронецький виокремлює два типи націоналізму: націоналізм ліберальний, заснований на ненависті, більше чи менше атеїстичний та неетичний, який не можна погодити 3 християнською етикою, шкідливий для панування миру у світі та морального розвитку національного життя; та націоналізм християнський, заснований на любові, який, нажаль, мало береться до уваги католицькими теологами та філософами, котрі сконцентровані на боротьбі з першим. Воронецький вважав, що християнський націоналізм заслуговує на особливу увагу, однак через ліберальний націоналізм натрапляє на упередження в католицьких середовищах, котрі піддаються впливу індивідуалізму та сучасного синтементалізму [10, с. 71].

В основі такого розрізнення лежить вчення св. Томи. Його докладніше деталізує у своїй праці Бохенський. Він відзначає, що ті, хто знаходиться під враженням від помилок, а точніше, крайнощів націоналізму, часто-густо впадають в іншу крайність та підтримують крайніх інтернаціоналістів, і також помиляються. Католицизм займає вище, синтетичне становище від обох. Св. Тома вчив, що чеснота протиставляється двом крайнощам, двом помилкам, однак стоїть завжди ближче котроїсь з них. Так само вважає і Бохенський: більше чужий духу католицизму, ніж найгірший націоналізм масонський чи радянський інтернаціоналізм [13, с. 30]. Однозначно негативно ставиться він і до лібералізму та всього, що з ним пов'язане. 
Для Бохенського теж важливим $є$ питання взаємин між державою, Церквою та нацією, їх взаємоповага та взаємозалежність. Услід за св. Томою він вважав, що Церква має право домагатися від держави забезпечення їй вільного розвитку та унеможливлення діяльності іï ворогів. А держава $є$ найвищою світською організацією суспільства та має мету забезпечити громадянам якнайповніший розвиток дочасного життя, гармонії та спокою, тобто тих меж, в яких повинно розвиватися життя надприродне. У розумінні св. Томи держава $є$ в певному розумінні тотальною, має власну католицьку програму та реалізує ії відповідно до можливостей [13, c. 24].

За Бохенським, державна влада повинна застосовувати примус. Він хоча і не є головним засобом, однак неодмінним для оборони перед злом. А зі злом обов'язково потрібно боротися, оскільки воно реально існує. Суперечити з цим може лише той, хто, на думку Бохенського, всі погляди та етичні основи оцінює однаково добре, не розрізняючи їх, хто відмовляє державі в ідеологічній функції. Такою $є$ ліберальна концепція.

Порушує Бохенський і питання взаємин Церкви та держави. Із трьох можливих концепцій (дві з яких - підпорядкування Церкви державі та підпорядкування держави Церкві) третя, а саме координація дій, найбільше відповідає сучасній католицькій думці $[13$, с. 25$]$. На його думку, за традиційною християнською концепцією помилковими $є$ політичний лібералізм, пацифізм та теорія убогих засобів, яку пропагують французькі теологи, зокрема i Ж. Марітен. Бохенський не сприймав думки про те, що в майбутньому католицька держава забезпечить рівні права всім єритикам, комуністам та всім ворогам віри та моральності $[13$, с. 26]. Таким чином, Бохенський вважає, що держава має бути передусім католицькою; вона повинна толерантно ставитися до не католиків, однак не більше. Типології націоналізму він не торкається, проте критикує лібералізм та комунізм. Ці напрями політичної думки критикує і Конрад. 
Метафізичне обгрунтування модерного націоналізму (ідеології) М. Конрад вбачає у філософії Ф. Ніцше. Дослідник відзначає, що Ніцше став для націоналізму тим, чим був Руссо для французької революції чи Маркс для модерного соціалізму та комунізму [6, с. 15]. Наслідки Французької революції та вчення Руссо критикує і Я.Воронецький. Так, наслідком революції він вбачав поширення таких течій сучасної йому думки, як ліберальний гуманітаризм, індивідуалізм, синтементалізм [10, с. 70]. Бохенський також критикує ліберальний гуманітаризм, навіть полемізує з цього приводу з Марітеном [13, с. 41-45]. Неприйняття синтезу томізму та, наприклад, у даному випадку, гуманізму, $є$ підтвердженням формування філософсько-теологічної думки цих мислителів у межах раннього неотомізму.

В основі ідеалу Ніцше лежить цілковито анархістичний крайній індивідуалізм, однак своєрідний через аристократизм та зневажливе ставлення до демократичної рівності. Йому не прийнятний ідеал надлюдини з іiі «безоглядним егоїзмом» та етичний аморалізм, визнання ворожості демократії для людини, антиінтелектуалізм. У цілому доповідач ставив за мету дати загальну характеристику філософії Ніцше та висвітлити найбільш неприйнятні її риси. Чому це важливо для мислителя? Його мета не теоретизувати, а науково-популярно пояснити ті процеси, які відбуваються в українському суспільстві. Адже, на думку Конрада, ніцшівську спекуляцію до українського націоналізму пристосував Дмитро Донцов. У цьому він вбачав низку небезпек. Найперше - це сліпа активність, яка, за Донцовим, має бути головним двигуном націоналістичного руху. Другорядність розумових мотивів у порівнянні з інстинктами, пристрастями, афектами. Інша небезпека - аморальність націоналізму Донцова. Спільна мораль не повинна мати над собою спільної санкції. Ї̈і критерій (чи дія) робить нас сильнішим чи ні. Із цієї точки зору можна виправдати погані вчинки та засудити добрі. Така мораль не приймає поняття справедливості та любові до ближнього. Таку концепцію, на думку Конрада, приймає частина молоді частково, 
а частина - в цілому. Конрад вважав, що під впливом концепції Донцова український модерний націоналізм формується 3 такими властивостями: тенденція до поневолення одиниці нацією, до боготворення нації, моральний релятивізм, недотримання принципів демократії, ненависть до ворогів, антисемітизм, у міжнародній політиці - суто політичний розрахунок [6, с. 15-23].

Як же ставиться сучасний католицизм до націоналізму? Конрад вважав їх близькими один до одного за властивими їм ідеалізмом та активністю. Це союзники у боротьбі 3 лібералізмом та соціалізмом [6, с. 23-24]. Націоналізм має протистояти лібералізму та марксизму. Та чи можлива ефективна боротьба, якщо їхня ментальність та мораль залишається, на думку Конрада, досить спорідненою? Для демонстрації цього він вибирає кілька площин. Найперше - релігійна. Тут їм притаманний скритий або відкритий атеїзм, який призводить до заперечення об'єктивної моралі, не залежної від людини, «особового, трансцендентного, поза світового Бога» [6, с. 26]. Водночас, відбувається обожнення сотворіння: в індивідуалістично-лібералістичній ментальності - індивіда, соціалістично-марксистській - суспільства, пролетаріату, в націоналістичній - нації. На думку Конрада, націю можна і треба ставити понад усе земне та світське, як найвищу другорядну мету людського життя. Однак ніколи нація не повинна бути найвищою метою взагалі. Навіть якщо модерний націоналістичний дух, або неонаціоналізм у Конрада й не відкидає офіційно релігію, то використовує ïi як засіб досягнення цілей, як у випадку з протестантизмом у Німеччині. Проте релігія є метою сама по собі і не може бути засобом для націоналізму. Вона містить вічні цінності, а нація - дочасні. Тому, на думку Конрада, нація повинна підпорядковуватися релігії. Дослідник цілком погоджується з томістичною теорією підпорядкування держави Церкві. Однак на той час української держави не існувало, що спонукало мислителя писати лише про націю. 
Інакше, вважав Конрад, виникне модерне поганство, коли створюються національні культи та церкви, як польська національна церква (В. Лютославські і А. Гурські) [6, с. 26-27]. Однак, релігія не суперечить здоровому націоналізму, та навіть сприяє найповнішому розвитку нації, $є$ коренем національної культури і могутності. На думку Конрада, розбудувати внутрішній зміст націоналізму на засадах католицизму - це завдання здорового i правильного націоналізму XX ст. [6, с. 27-28].

Так само і у площині нації та етики. Для всіх націй повинна бути понаднаціональна християнська етика. В іншому випадку скільки націй, стільки й етик [6, с. 29]. А у площині філософії, науки та культури сучасний Конраду націоналізм, на думку дослідника, спирається на засади ніцшеанізму, хитається між суперечними системами позитивізму, агностицизму, скептицизму, релятивізму, ірраціоналізму. Спостерігається у ньому недовіра до думки та культ вчинку. Наслідком такого стану ідеалістичного напряму - націоналізму, може стати сходження на матеріалістичну платформу супротивника, відзначав Конрад [6, с. 30-31].

У політично-суспільній площині неонаціоналізм ще перебуває під впливом марксистської ідеології. Між ними, попри позірні розбіжності, на думку отця, чимало спільного. Обом напрямам притаманний диктаторський абсолютизм держави, диктатура партії, революція, насилля, популістські способи агітації. Для першого - обожнення нації, для другого - держави. Для одного «статична господарська організація», для другого - державний етатизм. Проте націоналізм потенційно прагне до ідеалізму, а тому шукає співпраці з Церквою [6, с. 32].

Католицизм, на думку Конрада, є противником ніцшевського націоналізму, лібералізму та соціалізму. Оскільки ніцшеанізм виявився невдалим матеріалом для реалізації націоналістичних планів, то провідники неонаціоналізму повинні покинути цю платформу й споріднених з нею «ізмів» та зближатися 3 католицизмом. Цю тенденцію найбільш помітно в економічній сфері. І3 приходом до влади неонаціоналізм намагався вирішити економіч70

Institute of Philosophy of H. S. Skovoroda of NAS of Ukraine 
ну кризу. А це можливо, на думку Конрада, завдяки обмеженню безмежного егоїзму великих капіталістів - ядра ніцшеанізму. Змінити це можна лише завдяки альтруїзму, любові до ближнього, який є ядром католицизму. Лібералізм та більшовизм дбали про добро лише одного класу, а націоналізм - про добро всіх, а тому мав повернутися до альтруїзму та християнської науки. Націоналізм прагне забезпечити здоров’я нації, а його запорука - міцна родина, яку руйнує ніцшівська аморальність. А родину та статеву мораль ніщо так не зберігає, як католицизм. Тому і тут вони можуть стати союзниками. У теорії націоналізм має риси, ворожі католицизму, однак на практиці їх співпраця може ці риси нівелювати [6, с. 32-34].

На той момент (1933-1934) отцю здавалася така співпраця цілком реальною. Джерело цих надій він вбачав у підписаних конкордатах націоналістичних держав з Католицькою Церквою. Завдяки праці Церкви він бачив обнадійливі тенденції і в українському суспільстві (Обнова. Католицька Акція української молоді). Незважаючи на, поки що, нечітку позицію націоналістичних держав у справі виховання молоді на основі християнського, а першою чергою - католицького віровчення, отець плекав надію, що засади конкордатів сприятимуть порозумінню між націоналізмом та католицизмом [6, с. 35-37]. На це покладали надії і в Римі. Підкреслював значення конкордатів у співпраці Церкви та держави і Бохенський $[13$, с. 26]. Важливим був для оборони прав УГКЦ у міжвоєнній Польщі конкордат 1925 р. У міжвоєнний період ще зберігалася надія на позитивні зміни у націоналістичних суспільствах під впливом вчення Католицької Церкви, i вона не була безпідставною.

Коли мова заходить про практичне втілення обговорюваних понять у площині визвольних змагань українців, то Конрад підтримує боротьбу за створення Української незалежної держави та обгрунтовує його в межах природного закону томізму. Однак він вважав, що підгрунтя національних прагнень має бути 
християнським, а оскільки він був католицьким мислителем, - то й згідним із вченням Католицької Церкви. Конрад торкається у своєму дослідженні визначення ролі в історії кожної з націй, однак виразно не розвиває цю тему. Його головне завдання - узгодити український націоналізм 3 католицьким вченням.

Практичну сторону мають і погляди Воронецького та Бохенського. Так, Воронецький пише про них у площині трьох згаданих вище проблем. Перша проблема націоналізму - яке значення для повноти морального розвитку людини має життя, вміщене у національні межі? Від відповіді на це питання залежатиме розв'язання й інших проблем. А саме: що має найбільше значення для морального розвитку людини - держава чи нація? Відповідно до того, на думку Воронецького, у житті націй відбувається двояка тенденція. 3 одного боку, схильність до національної уніфікації держав, що складаються з кількох національностей. Як наслідок - виродження національних меншин та слабких і молодих націй 3 іншого боку, прагнення слабких національностей, що входять до складу певних держав, до виходу з такого утиску шляхом створення більш чи менш автономних держав [10, с. 63]. Враховуючи гостроту українського питання у міжвоєнній Польщі ці роздуми виглядають досить предметними та актуальними. Із ними пов'язані наступні питання.

Право прагнути певної національної однорідності держави, за Воронецьким, слушно прислуговує їй, як і нації, право до прагнення політичної автономії. Поєднання цих двох чинників, держави та нації, допомагає громадянам та значно збільшує їх моральні сили. Обом напрямам Воронецький радить бути розважливими та не прагнути надто швидкого поступу.

Друге питання стосується моральних прав, які керують діяльністю як держави, так і нації. Чи є вони такими самими, як ті, що зобов'язують одиницю людську, чи відмінними, і чому? Так, вони, на думку Воронецького, є відмінними. Ні держава, ні нація не можуть мати ту саму відповідальність, що особа. Не можуть брати на себе ті жертви та дії, що може особа. Те, що державі до- 
зволено, може бути не прийнятним для одиниці, та навпаки. Як тут окреслити поле діяльності нації, що не має власної політичної автономії? [10, с. 68]. Порушуючи це питання Воронецький не відповідає на нього, тільки виносить його на дискусію.

А як діяти у міжнаціональних конфліктах? На противагу ліберальному націоналізму, Воронецький вважав, що не сила йде перед правом, а навпаки - ніяка сила не може перемогти право у досягненні довгострокової мети. Однак, у випадку відсутності позитивного міжнародного права, взаємини між націями повинні врегульовуватися моральною силою, яка перевищує позитивне право, що міститься у звичаях та моральних цінностях націй у тій певного роду силі, що надає народам ніби цивілізаційну місію. У цьому контексті Воронецький пропонує подискутувати й замислитися над тим, чи та сила моральна, яку цивілізація глибоко християнська здатна дати народам, не наділяє їх одночасно певними правами експансії, особливо якщо підтримання їхнього морального життя того вимагає [10, с. 68].

Третя проблема стосується питання зв'язку між життям національним та надприроднім. Тут Воронецький торкається поняття патріотизму та націоналізму. Розмірковуючи про справжній християнський патріотизм, він нагадує про християнський обов'язок любові до ближнього, порядок його застосування та пристосування до нових проблем сучасності [10, с. 69]. Хоча він виразно не пов'язує християнський націоналізм із християнським патріотизмом, та такий натяк у його викладі присутній.

Продовжуючи думку, Воронецький пише про покликання солдата-християнина, про яке, як вів вважає, мало пишуть, та про війну як жертву в ім’я християнської любові, а не лише як жорстоку бійню, натхненну ненавистю. Як приклад він наводить листи 3 фронту солдат, які загинули у Франції за часів Першої світової війни. Для них війна була очищенням та удосконаленням їх моральних якостей. У тих солдат у ставленні до їх ворогів можна побачити гнів, обурення, бажання відкинути ворога, обороняючи 
своїх, покарати його за скоєнні злочини, проте не можна знайти ненависті [10, с. 69-70].

Бохенський підтримує запропоновану Воронецьким дискусію. Відповідно до католицького вчення кожна нація має не лише право, а й обов'язок розвиватися, а в разі потреби - обороняти свою культуру. Католицизм може дати націоналізму універсальне підгрунтя, в ім'я якого націоналіст, відстоюючи права власної нації, вчиняє згідно з потребами світової культури. Оскільки національна культура, поміж іншими, об'єднує цінності понад матеріальні, значення яких може бути вищим, ніж значення людського життя, з метою їх оборони можна і потрібно, у разі потреби, вести війну. Обмеженням для націоналізму $є$ прагнення інших націй, якщо вони мають правдиву, а не псевдо культуру.

Націоналізм, який прагне захопити весь світ для знищення інших культур та підкорення їх власній, з католицизмом не погоджується. Однак не бачить жодної незгоди там, де йдеться про псевдо-культури, однією з яких $є$ комуністична. Місію Польщі Бохенський вбачає в обороні християнства. А відтак йому здається, що війна Польщі із сучасною йому Росією виключно $з$ метою звільнення певної території з-під впливу комуністичної псевдокультури не наразилася б на суперечність 3 католицьким вченням, якби діяла згідно з його засадами [13, с. 87-88]. Таким чином, на думку Боденського, експансія можлива за певних обставин.

Кожна нація має право боронити свою культуру від інших, проте не має жодного права відбирати культуру в інших. Обидві культури є відтінками загальнолюдської культури, а тому нищити ïx не можна I не лише силою, а й іншими засобами, наприклад, адміністративними репресіями. Бохенський відзначав щодо цього: «Особисто вважаю, що позиція багатьох поляків щодо українського питання була не католицькою» [13, с. 96]. Продовжуючи думку додав, що українська нація репрезентує певну культуру, і то культуру християнську, яку, в ім'я добра світової культури, має право розвивати, як і кожна інша нація. 
Порівняно з польськими мислителями-неотомістами Конрад не підтримує експансіоністського націоналізму. У межах природного закону він обстоює право поневолених націй на незалежність. Він вважає, що державний правовий націоналізм $є$ суперечним з імперіалізмом та крайнім національним егоїзмом.

Загалом, проведене дослідження дало можливість, на основі аналізу засадничих понять націоналізму, з'ясувати бачення о. М. Конрадом альтернативного інтегральному націоналізму Д. Донцова вчення, а саме - націоналізму католицького. Також ствердити, що мислителю вдалося розвинути власне грунтовне i виважене бачення проблеми, яке можна окреслити як католицький націоналізм. У результаті вивчення його ідей було з'ясовано, що вони містяться на межі двох філософських напрямів - неотомізму та політичної філософії. Однією з причин ідеї розвитку націоналізму на християнських засадах була потреба протиставити iii інтегральному націоналізму Д. Донцова, який перебував під впливом філософії $\Phi$. Ніцше. Спільність розуміння поняття національної ідентичності, сутності націоналізму та його видів Конрадом i сучасними мислителями (В. Лісовий, О. Проценко, Е. Сміт) засвідчує далекоглядність та актуальність ідей отця з царини політичної філософії.

Порівняння доповіді М. Конрада з працями польських мислителів Я. Воронецького та Ю. Бохенського дало можливість стверджувати, що його ідея католицького націоналізму розвивалася у межах політико-філософського дискурсу з приводу розвитку, поширення та впровадження націоналістичних ідей як у польському, так і в українському середовищі. Отці М. Конрад, Я. Воронецький та Ю. Бохенський у своїх роздумах намагалися розглядати проблему націоналізму на засадах вчення Томи Аквінського, зокрема про природній закон, загальне добро, вчення про державу, застосовуючи його до проблем тогочасного суспільства, посилаючись при цьому на документи Католицької Церкви, що властиво ранньому неотомізму та християнській етиці. 
Проте на основі вчення католицизму та Томи з Аквіну польським мислителям вдалося обгрунтувати місце Польщі в історії світової культури та розробити власне бачення прагнення до експансії польської нації. Натомість Конраду, на основі вчення католицизму та неотомізму, оперуючи поняттями політичної філософії, вдалося обгрунтувати право української нації на незалежність. Однак Конрад розвивав свою думку переважно у межах політичної філософії, ніж етики, а Воронецький та Бохенський - саме у царині етики.

Не зважаючи на науковий підхід, його виклад залишається зрозумілим та не надто переобтяженим науковими термінами, що сприяло популярності філософських ідей та Академічних вечорів. В огляді виступу о. д-ра Конрада на тему «Націоналізм та католицизм», вміщеному у тогочасному часописі «Мета», відзначалося, що його слухала численна аудиторія з різних кіл українського суспільства, переважно студенти [21, с. 7]. Доповідь М. Конрада була актуальною та відповідала запитам сучасного українського суспільства. За їі допомогою він намагався вплинути на формування української релігійної та національної ідентичності, застерегти українську громадськість перед крайнощами інтегрального націоналізму. Натомість пропонував поміркований варіант націоналізму, заснований на християнських засадах та вченні католицької церкви.

\section{ЛІТЕРАТУРА ТА ПРИМІТКИ}

1. Smis D. Anthony. Nacjonalizm. Teoria, ideologia, historia. Warszawa, 2007. $212 \mathrm{~s}$.

2. Сміт Д. Ентоні. Націоналізм. Теорія, ідеологія, історія. К., 2004. URL: http://litopys.org.ua/smith/smt.htm

3. Світильник істини: Джерела до історії Української Католицької Богословської Академії у Львові (1928/29-1944) // Упорядн. д-р Павло Сениця. Частина друга. Торонто-Чікаго, 1976. 663 с. 
4. Мизак Н. Діяльність Богословського наукового товариства Української греко-католицької церкви у 1923-1939 рр. // Релігія та Соціум. 2013. № 3-4. С. 109-117.

5. Лісовий В. Ідеологія націоналізму // Культура - ідеологія - політика. К., 1997. 352 с.

6. Конрад М. о. Др. Націоналізм і католицизм. Івано-Франківськ, 2003. $37 \mathrm{c}$.

7. Лісовий В. Проиенко О. Націоналізм, нація та національна держава // Націоналізм. Теорії нації та націоналізму від Йогана Фіхте до Ернеста Гелнера: Антологія. К., 2006. xIiv +684 c.

8. Лісовий В. Продовжуємо обговорення: націоналізм та патріотизм // Культура - ідеологія - політика. К., 1997. 352 с. С. 336-350.

9. Nacjonalizm a katolicyzm: Opinije biskupów, uczonych, polityków i publicystów współczesnych. Poznań, 1927. 149 s.

10. Woroniecki J. O narodzie i państwie. Lublin, 2004. $71 \mathrm{~s}$.

11. Pawlak M. Państwo i Kościół w myśli św. Tomasza z Akwinu i Marsyliusza z Padwy // Rocznik Tomistyczny, 2015. S. 163-189.

12. Św. Tomasza z Akwinu. Dzieła wybrane. Kęty, 1999. 694 s.

13. Bocheński J.M. Szkice o nacjonalizmie i katolicyzmie polskim. Komorów, 2006. 125 s.

14. Сміт Д. Ентоні. Національна ідентичність. К., 1994. С. 224.

15. Woroniecki J. Katolicka etyka wychowawcza: w 3 t. T. 1. Lublin, 2013. $481 \mathrm{~s}$.

16. Charakter narodowy i reliqia: zbiór tekstów. Lublin, 1997. 133 s.

17. Конрад М. о. Др. Націоналізм і Католицизм // Мета. Ч. 31. 12 серпня 1934 р. С. 2-3.

18. Лісовий $B$. Націоналізм // Філософський енциклопедичний словник. К., 2002. 743 с.

19. Конрад М. о. Др. Націоналізм і Католицизм // Мета. Ч. 32. 19 серпня 1934 р. 3-4.

20. Лісовий В. Драгоманов і Донцов // Культура - ідеологія - політика. К., 1997. 352 с. С. 253-261.

21. «о. Др. М. Конрад. Католицизм і націоналізм»// Мета. Ч. 16. 29 квітня 1934 р. С. 7.

22. Праця видана вперше французькою мовою у 1924 р. та перевидана польською у 1927 р. у збірці під назвою «Націоналізм та католицизм: Думки єпископів, вчених, політиків та публіцистів» (Познань, 1927). Ця збірка була зініційована Мауріцио Васардом у

Інститут філософії імені Г. С. Сковороди НАН України 
1924 р. та вийшла друком того самого року в Парижі. Праця відображала погляди не лише поляків, а й представників інших країн - Франції, Німеччини, Бельгії, Австрії, Іспанії, Угорщини, Ірландії, Італії, Швейцарії, що доводить існування дискурсу на тему «націоналізм та католицизм» у перелічених європейських країнах [9]. У 2004 р. погляди про націоналізм Я. Воронецького перевидані у Любліні із ще однією працею автора під назвою «Про націю та державу» [10].

23. Докладніше про це йдеться у праці Юзефа Яроня «Національний характер як наукова проблема» та Леха Здибеля «Польський національний характер - націоналістичний аналіз проблеми» у збірці «Charakter narodowy i reliqia: zibór tekstów» (Люблін, 1997) [16].

\section{REFERENCES}

1. Smith, D. (2007). Anthony. Nationalism. Theory, Ideology, History. Warsaw.

2. Smith, D. (2004). Anthony. Nationalism. Theory, Ideology, History. Retrieved from http://litopys.org.ua/smith/smt.htm [In Ukrainian].

3. The Luminaire of Truth: Sources to the History of the Ukrainian Catholic Theological Academy in Lviv (1928/29-1944). (1976). In Dr. Paul S. Senitsa (Compiler). Part 2. Toronto-Chicago. [In Ukrainian].

4. Myzak, N. (2013). Activities of the Theological Scientific Society of the Ukrainian Greek Catholic Church in 1923-1939. Relihiya ta Sotsium (Religion and Society), 3-4, 109-117. [In Ukrainian].

5. Lisovyi, V. (1997). The Ideology of Nationalism. Kyiv. [In Ukrainian].

6. Konrad, M. (2003). Father Dr. Nationalism and Catholicism. IvanoFrankivsk. [In Ukrainian].

7. Lisovyi, V. Protsenko, O. (2006). Nationalism, Nation and National State. In Nationalism. Theories of Nation and Nationalism from Johann Fichte to Ernest Gellner: Anthology. Kyiv. [In Ukrainian].

8. Lisovyi, V. (1997). We continue the discussion: nationalism and patriotism. In Culture - Ideology - Politics (pp. 336-350). Kyiv. [In Ukrainian].

9. Nacjonalizm a katolicyzm: Opinije biskupów, uczonych, polityków i publicystów współczesnych. (1927). Poznań.

10. Woroniecki, J. (2004). O narodzie i państwie. Lublin. 
11. Pawlak, M. (2015). Państwo i Kościół w myśli św. Tomasza z Akwinu i Marsyliusza z Padwy. Rocznik Tomistyczny, 163-189.

12. Św. Tomasza z Akwinu. (1999). Dzieła wybrane. Kęty.

13. Bocheński, J. M. (2006). Szkice o nacjonalizmie i katolicyzmie polskim. Komorów.

14. Smith, D. (1994). Anthony. National Identity. Kyiv. [In Ukrainian].

15. Woroniecki, J. (2013). Catholic Educational Ethics. In 3 vol. V. 1. Lublin.

16. Charakter narodowy i reliqia: zbiór tekstów. (1997). Lublin.

17. Konrad, M. (1934, August). Father Dr. Nationalism and Catholicism. Meta (Goal), 31, 2-3. [In Ukrainian].

18. Lisovyi, V. (2002). Nationalism. In Philosophical Encyclopedic Dictionary. Kyiv.

19. Konrad, M. Father Dr. (1934, August, 19). Nationalism and Catholic. Meta (Goal), 3-4. [In Ukrainian].

20. Lisovyi, V. (1997). Drahomanov and Dontsov. In Culture - Ideology Politics (pp. 253-261). Kyiv. [In Ukrainian].

21. Father Dr. M. Konrad Catholicism and Nationalism. (1934, April, 29). Meta (Goal), 16. [In Ukrainian].

\section{Oksana Sheremeta}

Candidate of Philosophical Sciences (Ph. D.), Junior Researcher H.Skovoroda Institute of Philosophy of the NAS of Ukraine e-mail: osheremeta2015@gmail.com

ORCID: https://orcid.org/0000-0001-8364-4300

\section{Father Mykola Conrad: Formation of Ukrainian National Identity in the Context of «Nationalism and Catholicism» Problem}

\section{Abstract}

The article covers the views of M.Conrad on nationalism and the related concepts of national identity, nation, national state in the context of the «Nationalism and Catholicism» problem. M. Conrad expressed his thoughts on national- 
ism in a report titled «Nationalism and Catholicism» written to be presented at the Academic Evenings of the Theological Scientific Society.

The study made it possible, on the basis of analysis of the basic concepts of nationalism, to find out the vision of $M$. Conrad's alternative doctrine to the integral nationalism of $D$. Dontsov, which is Catholic nationalism. It also made it possible to prove that the thinker managed to develop a well-grounded and well-balanced vision of a problem that can be described as Catholic nationalism. As a result of the study of his ideas it was found that they are on the verge of two philosophical directions - neo-Thomism and political philosophy. One of the reasons for the idea of developing nationalism on a Christian basis was the need to oppose it to the integral nationalism of D. Dontsov, who was influenced by the philosophy of F. Nietzsche. The shared understanding of the concept of national identity, the essence of nationalism and its types by Conrad and contemporary thinkers (V. Lisovy, O. Protsenko, E. Smith) shows the foresight and the relevance of the ideas of the father in the realm of political philosophy. Comparison of the report by M. Konrad with the works of Polish thinkers Y. Voronetsky and Y. Bohensky provided an opportunity to argue that his idea of Catholic nationalism developed within the framework of politicalphilosophical discourse on the development of the spread and implementation of nationalistic ideas both in Polish and Ukrainian environments. Fathers M. Conrad, Y. Voronetsky and Y. Bohensky tried to consider the problem of nationalism on the basis of early neo-Thomism, in particular, the doctrine of the natural law, the common good, the doctrine of the state, applying it to the problems of the contemporary society.

Keywords: neo-Thomism, political philosophy, national identity, nationalism, nation, national state

\section{Оксана Шеремета}

младиий научный сотрудник

Институт философии имени Г. С. Сковородьл НАН Украинь

e-mail:osheremeta2015@gmail.com

ORCID: https://orcid.org/0000-0001-8364-4300 


\section{о. Николай Конрад: формирование украинской национальной иден- тичности в контексте проблемы «национализм и католицизм»}

\section{Аннотация}

В статье освещаются взгляды о. Н. Конрада на наџионализм и связаннье с ним понятия: национальная идентичность, наџия, национальное государство в контексте проблемь «национализм и католицизм», которые он высказал в докладе под названием «Национализм и католицизм», написанном для выступления на Академических вечерах Богословского Научного общества. Проведенное исследование позволило на основе анализа основных понятий начионализма выяснить видение Н. Конрадом альтернативного учения в интегрального начионализма Д. Донщова - начионализма католического. Отмечается, что мыслителю удалось развить собственное основательное и взвешенное видение проблемы, которое можно определить как католический национализм. В результате изучения его идей было выяснено, что они находятся на границе двух философских направлений - неотомизма и политической философии. Одной из причин идеи развития национализма на христианских началах была потребность противопоставить ее интегральному национализму Д. Донщова, который находился под влиянием философии Нищще. Общность понимания понятия национальной идентичности, сущности наџионализма и его видов Конрадом и современными мыслителями (В. Лесной, А. Проченко, Э. Смит) свидетельствует о дальновидности и актуальности идей отща в области политической философии. Сравнение доклада Н. Конрада с трудами польских мыслителей Я. Воронецкого и Ю. Бохенского позволило утверждать, что его идея католического национализма развивалась в рамках политико-философского дискурса по развитию, распространению и внедрению националистических идей как в польской, так и в украинской среде. Н. Конрад, Я. Воронецкий и Ю. Бохенский пытались рассматривать проблему национализма на основе раннего неотомизма, в частности учения о природном законе, общем благе, учении о государстве, применяя его к проблемам общества того времени.

Ключевые слова: неотомизм, политическая философия, начиональная идентичность, национализм, наџия, национальное государство. 